\title{
RHENIUM AND MOLYBDENUM IN TERTIARY OIL SHALE DEPOSITS IN NORTHWESTHERN ANATOLIA, TURKEY
}

\author{
R. KARA GÜLBAY* \\ Department of Geological Engineering \\ Karadeniz Technical University \\ 61080, Trabzon, Turkey
}

In this study, TOC content, Re-Mo enrichment and depositional environment of oil shale deposits in NW Anatolia are investigated.

The Hatıldă̆, Himmetoğlu, Beypazarı, Bahçecik, Seyitömer and Gölpazarı oil shale units are characterized by average TOC values $5.62 ; 6.52 ; 7.73$; $8.68 ; 12.85$ and $6.85 w t . \%$, average Re concentrations 5.52; 3.55; 5.77; 4.45; 2.43 and $10.43 \mathrm{ng} / \mathrm{g}$, and average Mo concentrations 2.86; 1.60; 10.17; 1.00; 1.63 and $7.11 \mu \mathrm{g} / \mathrm{g}$, respectively. Although the data on TOC content are similar, Re and Mo content of these oil shales is lower than those of the marine black shales of the Norwegian and Cenomanian-Turonian boundary event (CTBE) and of Mediterranean sapropels.

Re and Mo concentrations in all Turkish oil shale areas are higher with respect to average values for shales. The enrichment factors $(E F)$ for Re and Mo are the highest for Beypazarl - 310-107, and the lowest for Bahçecik35.17-1.57.

The following significant correlations were established: Re-Mo for Hatıldağ, Re-TOC and Re-U for Himmetoğlu, Re-Mo and U-TOC for Beypazarl, Re-Mo and Re-U for Bahçecik and Re-TOC, Mo-TOC, U-TOC, $R e-U$ and Mo-U for Seyitömer oil shales. No significant correlation was determined between any of the variables from the Gölpazarl field.

\section{Introduction}

Northwestern part of Turkey hosts six important Tertiary oil shale fields which contain 1.6 billion tonnes oil shale reserves. These fields are Beypazarı (Ankara), Seyitömer (Kütahya), Himmetoğlu and Hatıldağ (Bolu), Gölpazarı (Bilecik) and Bahçecik (İzmit).

Geologic and economical characteristics of these fields have been studied by several workers. Kök [1] and Altun et al. [2] have studied oil shale

\footnotetext{
*Corresponding author: e-mail kara@ktu.edu.tr
} 
resources in Turkey and in other countries of the world. The Bahçecik field was studied by Talu [3], the Gölpazarı field by Yanılmaz et al. [4], the Himmetoğlu field by Taka and Şener [5], the Beypazarı field by Şener and Şengüler [6], the Seyitömer field by Şener and Şengüler [7], and the Hatıldağ field by Şener and Şengüler [8]. In addition, Şener et al. [9] have investigated geologic-geochemical characteristics and economical values of Himmetoğlu, Seyitömer, Beypazarı and Hatıldağ oil shales. Organic-geochemical features of the Himmetoğlu field have been studied by Sarı [10], the Beypazarı field by Özçelik [11] and oil shale deposits in NW Anatolia by Kara-Gülbay and Korkmaz [12].

Thinly laminated rocks with total organic carbon content higher than 1 wt.\% are called black shales [13]. Fine-grained, black colored, laminated sedimentary rocks which generally yield commercial oil at pyrolysis are known as oil shales [14]. According to these descriptions, oil shales and black shales are quite similar, and the only difference between them is that oil shales contain more organic matter.

It is known that in comparison to normal shales, black shales are more rich in some trace elements [15-17]. Oil shales like black shales are also rich in trace elements [18]. It is stated that enrichment with trace elements is associated with anoxic depositional conditions of black shales. Some trace element ratios are suggested as the criterion for paleoredox conditions of deposition environment of sediments and sedimentary rocks rich in organic matter [17, 19-26]. Compared to other trace elements, Re and Mo are accumulated in larger quantities particularly in sediments rich in organic matter deposited at reducing conditions. This is due to the fact that accumulation of Re and Mo is directly related to paleoredox conditions [27].

In this study, distribution of Re and Mo in the Hatıldağ, Himmetoğlu, Beypazarı, Bahçecik, Seyitömer and Gölpazarı oil shale deposits of Tertiary age in NW Turkey, their similar and different characteristics as well as possible relation to TOC content were investigated. In addition to $\mathrm{Re}$ and Mo, uranium concentrations were also evaluated since these elements are paragenetically associated with each other $[18,28]$. Data obtained from experiments with these oil shales were correlated with the corresponding data on black shales and sapropels rich in organic matter.

Correlation matrixes, distribution tests and significance tests of regression lines used in the study were performed with the use of SPSS 9.0 statistical program. The bivariate diagrams and regression lines were drawn with Grapher 2.0 program.

It was checked whether the data on $\mathrm{Re}, \mathrm{Mo}, \mathrm{U}, \mathrm{Al}$ and TOC have a normal distribution. Arithmetic and geometric averages were used to calculate normal and logarithmic distribution, respectively, and the calculations were made with respect to these values. 


\section{Geological setting}

The Beypazarı, Seyitömer, Himmetoğlu, Hatıldağ, Gölpazarı and Bahçecik oil shale deposits in northwestern Anatolian region are found in Tertiary basins and alternated with Tertiary sequences (Fig. 1). Hatıldağ oil shales are found in the Paleocene-Eocene deposits [8], Gölpazarı-Bahçecik oil shales in the Oligocene units [3,4] and Beypazar1-Seyitömer-Himmetoğlu oil shales in the Miocene deposits [5-7, 29] The main characteristics of oil shale fields are given below.

The basement of the Beypazan field is composed of Paleozoic metamorphic rocks which are unconformably overlain by Tertiary deposits. The lower part of the oil shale unit is comprised by lignites. Oil shales in this field alternate with limestone, marl, claystone and tuffites. Oil shales show distinct lamination and schistosity. Drilling data indicate that the thickness of oil shale sequence is $57-111 \mathrm{~m}$. Oil shale reserves of the field are 330 million tonnes.

The basement of the Seyitömer field is composed of ophiolitic mélange which is unconformably overlain by Miocene deposits that also contain oil shales. The lower part of oil shales is comprised by lignites, and shales alternate with claystone, marl and silicified limestones. Oil shales of the field are brown, gray and greenish, and they display distinct lamination and schistosity. On the basis of drilling data, thickness of the oil shale sequence is $8.5-50 \mathrm{~m}$. The field hosts oil shale reserves of 120 million tonnes.

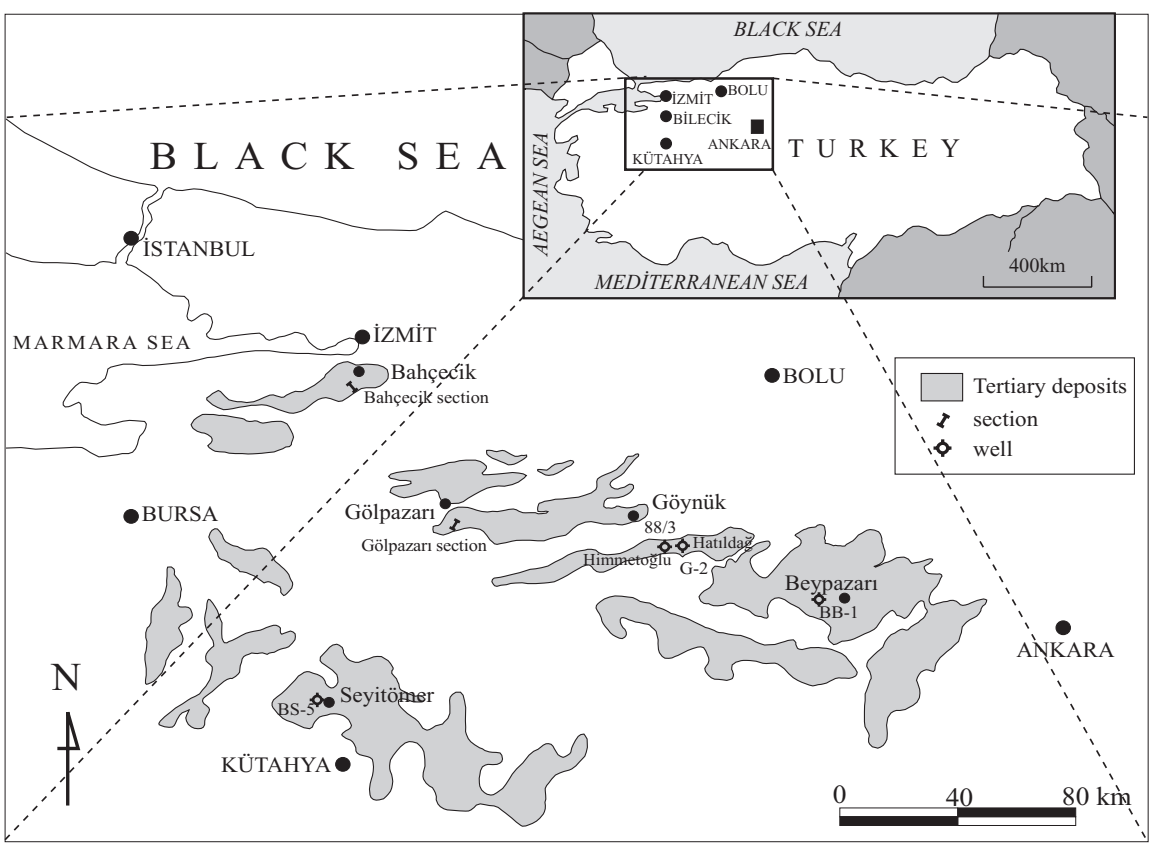

Fig. 1. Distribution of oil shale deposits of Tertiary age in NW Anatolia and locations of boreholes and type sections of oil shales. 
The basement of the Himmetoğlu and Hatıldağ fields is composed of Upper Cretaceous clastic rocks. The lower part of the Himmetoğlu oil shales is made up by a lignite level. Oil shales alternate with claystone, tuffites, marl and limestones. The color of oil shales varies from light to dark gray and seames are characterized by a distinct lamination. In borehole No. 88/3, thickness of the sequence is $84 \mathrm{~m}$. The Himmetoğlu field contains oil shale reserves of 660 million tonnes.

Oil shales exposing in the Hatıldağ field alternate with claystone, siltstone and marls. These oil shales are brown, brownish-gray and beige and show a distinct lamination in light-dark colors. Drilling data indicate that thickness of oil shales in this field varies from 26 to $120 \mathrm{~m}$. Oil shale reserves of the Hatıldag field are 360 million tonnes.

The basement of the Gölpazarı field is composed of Jurassic limestones and Upper Cretaceous clastic rocks. These oil shales are generally alternated with marls which contain limestone and sandstone interlayers. The oil shales in this field are brown-gray and show not distinct lamination. The thickness of oil shale unit was measured to be $46 \mathrm{~m}$, and, 7 oil shale levels were determined, their thickness ranging from 20 to $150 \mathrm{~cm}$. Oil shale reserves of the Gölpazarı field are 120 million tonnes.

The basement of the Bahçecik field is composed of upper Cretaceous limestones. Oil shales in the field alternate with marls which contain tuffiteclaystone-limestone interlayers. The oil shales are dark brown - black and show distinct lamination and schistosity. Since most part of the field is covered with vegetation, only a $38 \mathrm{~m}$-thick part of the sequence was studied, and oil shale bands with thickness ranging from 20 to $250 \mathrm{~cm}$ were observed. Oil shale reserves of the Bahçecik field are 40 million tonnes.

\section{Experimental}

Some of oil shale samples were taken from borehole cores and some from the exposures. Oil shale samples in the Himmetoğlu, Hatıldağ, Beypazarı and Seyitömer fields were taken from cores of the boreholes opened by the General Directorate of Mineral Research and Exploration of Turkey (MTA). In the Bahçecik and Gölpazarı fields, stratigraphic units were measured from oil shale sequences. 42 core samples were taken from borehole $88 / 3$ (Himmetoğlu), 47 samples from borehole G-2 (Hatıldağ), 31 samples from borehole BB-1 (Beypazarı) and 14 samples from borehole BS-5 (Seyitömer). 20 samples were taken from the Bahçecik field and 12 samples from the Gölpazarı field. TOC abundances of a total of 167 oil shale samples were analyzed with Leco, and concentrations of $\mathrm{Re}, \mathrm{Mo}, \mathrm{U}$ and $\mathrm{Al}$ were determined with the ICP/ES-MS method. The analyses were performed in the Acme Laboratories in Canada.

$2 \mathrm{~g}$ pulverized whole rock oil shale samples were digested with warm $15 \% \mathrm{HClO}_{4}$ and evolved $\mathrm{CO}_{2}$ was analyzed by Leco for total organic carbon 
amounts. At using the ICP/ES-MS method, $0.5 \mathrm{~g}$ pulverized sample was leached with $3 \mathrm{ml}$ of $\mathrm{HCl}-\mathrm{HNO}_{3}-\mathrm{H}_{2} \mathrm{O}(2+2+2)$ mixture at $95^{\circ} \mathrm{C}$ for one hour and diluted to $10 \mathrm{ml}$. Detection limits for $\mathrm{Re}(\mathrm{ng} / \mathrm{g}), \mathrm{Mo}(\mu \mathrm{g} / \mathrm{g}), \mathrm{U}(\mu \mathrm{g} / \mathrm{g})$ and $\mathrm{Al}(\%)$ are 1, 0.01, 0.1 and 0.01 , respectively.

\section{Results and discussion}

\section{Re, Mo, $U$ and TOC content}

TOC content of the Hatıldağ, Himmetoğlu, Beypazarı, Bahçecik, Seyitömer and Gölpazarı oil shales varies between $0.57-29.4 ; 0.59-18.5$; 0.83-15.06; $0.29-15.95 ; 3.68-31.96$ and $5.53-15.00 \mathrm{wt} . \%$, respectively, and average values computed for the respective fields are given in Table 1. In general, TOC values of shales of the fields are quite high, and there is no significant difference between TOC content measured for different areas.

Re concentrations of oil shales from the Hatıldağ, Himmetoğlu, Seyitömer, Beypazarı, Bahçecik and Gölpazarı fields are $1-48 ; 1-13 ; 1-15 ; 1-10 ; 1-5$ and 3-43 ng/g, respectively, and their average values are also given in Table 1. It was determined that Re concentrations of the Hatıldağ and Gölpazarı fields vary in a wide range, but the concentration range in other fields is narrow (Fig. 2).

Table 1. Basic statistical characteristics of Re, Mo, $\mathrm{U}$ and $\mathrm{Al}$ and TOC content for oil shale samples

\begin{tabular}{|c|c|c|c|c|c|c|c|c|c|c|c|c|c|c|}
\hline & \multicolumn{7}{|c|}{ Hatıldağ $(\mathrm{n}=47)$} & \multicolumn{7}{|c|}{ Himmetoğlu $(n=42)$} \\
\hline & Avr. & Std. & Min. & Max. & Mod. & Med. & Geo. & Avr. & Std. & Min. & Max. & Mod. & Med. & Geo. \\
\hline TOC ( & 8.01 & 6.83 & 0.56 & 29.43 & 6.42 & 6.97 & $560 \%$ & 6.47 & 4.02 & 0.59 & 18.50 & 4.73 & 5.30 & 5.42 \\
\hline $\operatorname{Re}$ & 9.21 & 10.14 & 1.00 & 48.00 & 2.00 & 5.00 & $5.52 *$ & 4.67 & 3.40 & 1.00 & 13.00 & 2.00 & 4.00 & $3.55^{*}$ \\
\hline $\mathrm{g} / \mathrm{g})$ & 4.56 & 5.05 & 0.25 & 28.50 & 0.25 & 3.48 & $2.86^{*}$ & 2.55 & 3.33 & 0.29 & 17.00 & 3.79 & .60 & $60 *$ \\
\hline & 1.25 & 1.09 & 0.10 & 5.20 & 1.09 & 0.90 & 0.92 & 3.30 & 2.04 & 0.40 & 10.70 & 1.70 & 2.70 & 2.78 \\
\hline \multirow[t]{3}{*}{$\mathrm{Al}(\%)$} & 0.97 & 0.85 & 0.01 & 3.93 & 0.53 & 0.67 & $0.62 *$ & 1.50 & 0.90 & 0.06 & 3.01 & 0.55 & 1.30 & 1.16 \\
\hline & \multicolumn{7}{|c|}{ Beypazarı $(n=31)$} & \multicolumn{7}{|c|}{ Seyitömer $(n=14)$} \\
\hline & Avr. & Std. & Min. & Max. & Mod. & Med. & Geo. & Avr. & Std. & Min. & Max. & Mod. & Med. & Geo. \\
\hline TOC & 7.73 & 3.81 & 0.83 & 15.06 & 0.83 & 7.71 & 6.50 & 12.85 & 8.51 & 3.68 & 31.96 & 3.68 & 10.51 & 10.54 \\
\hline $\operatorname{Re}(\mathrm{ng} / \mathrm{g})$ & 5.77 & 3.49 & 1.00 & 15.00 & 4.00 & 5.00 & 4.77 & 2.43 & 1.50 & 1.00 & 5.00 & 1.00 & 2.00 & 2.02 \\
\hline Mo $(\mu \mathrm{g} / \mathrm{g})$ & 10.17 & 5.98 & 0.45 & 25.42 & 0.45 & 8.69 & 8.17 & 1.63 & 0.88 & 0.53 & 3.52 & 0.53 & 1.60 & 1.37 \\
\hline $\mathrm{U}(\mu \mathrm{g} / \mathrm{g})$ & 2.31 & 2.14 & 0.20 & 9.50 & 1.50 & 1.50 & $1.62 *$ & 0.84 & 0.40 & 0.20 & 1.50 & 0.50 & 0.80 & 0.73 \\
\hline \multirow[t]{3}{*}{$\mathrm{Al}(\%)$} & 0.42 & 0.34 & 0.03 & 1.45 & 0.20 & 0.31 & $0.31 *$ & 0.60 & 0.24 & 0.02 & 0.90 & 0.02 & 0.67 & 0.48 \\
\hline & \multicolumn{7}{|c|}{ Bahçecik $(\mathrm{n}=20)$} & \multicolumn{7}{|c|}{ Gölpazarı $(n=12)$} \\
\hline & Avr. & Std. & Min. & Max. & Mod. & Med. & Geo. & Avr. & Std. & Min. & Max. & Mod. & Med. & Geo. \\
\hline TOC (wt.\%) & 8.68 & 4.26 & 0.29 & 15.95 & 0.29 & 8.37 & 7.03 & 6.85 & 4.16 & 3.53 & 15.00 & 3.53 & 4.80 & 5.95 \\
\hline $\operatorname{Re}(\mathrm{ng} / \mathrm{g})$ & 4.45 & 2.72 & 1.00 & 10.00 & 1.00 & 4.50 & 3.51 & 13.17 & 10.79 & 3.00 & 43.00 & 6.00 & 9.50 & $10.43^{*}$ \\
\hline & 1.00 & 0.54 & 0.14 & 2.32 & 0.72 & 0.97 & 0.83 & 7.11 & 5.82 & 0.51 & 19.41 & 0.51 & 5.09 & 5.09 \\
\hline $\mathrm{U}(\mu \mathrm{g} / \mathrm{g})$ & 0.93 & 0.49 & 0.20 & 2.20 & 1.00 & 0.90 & $0.80^{*}$ & 2.50 & 0.62 & 1.50 & 3.40 & 2.00 & 2.55 & 2.43 \\
\hline $\mathrm{Al}(\%)$ & 2.20 & 0.67 & 1.36 & 3.57 & 1.36 & 2.08 & $2.11 *$ & 1.63 & 0.55 & 0.83 & 2.78 & 0.83 & 1.56 & 1.55 \\
\hline
\end{tabular}

*Logarithmic values are of normal distribution and geometric averages were considered. Avr. - average, Std. - standard deviation, Min. - minimum, Max. - maximum, Mod. - mode, Med. - median, Geo. - geometric mean. 


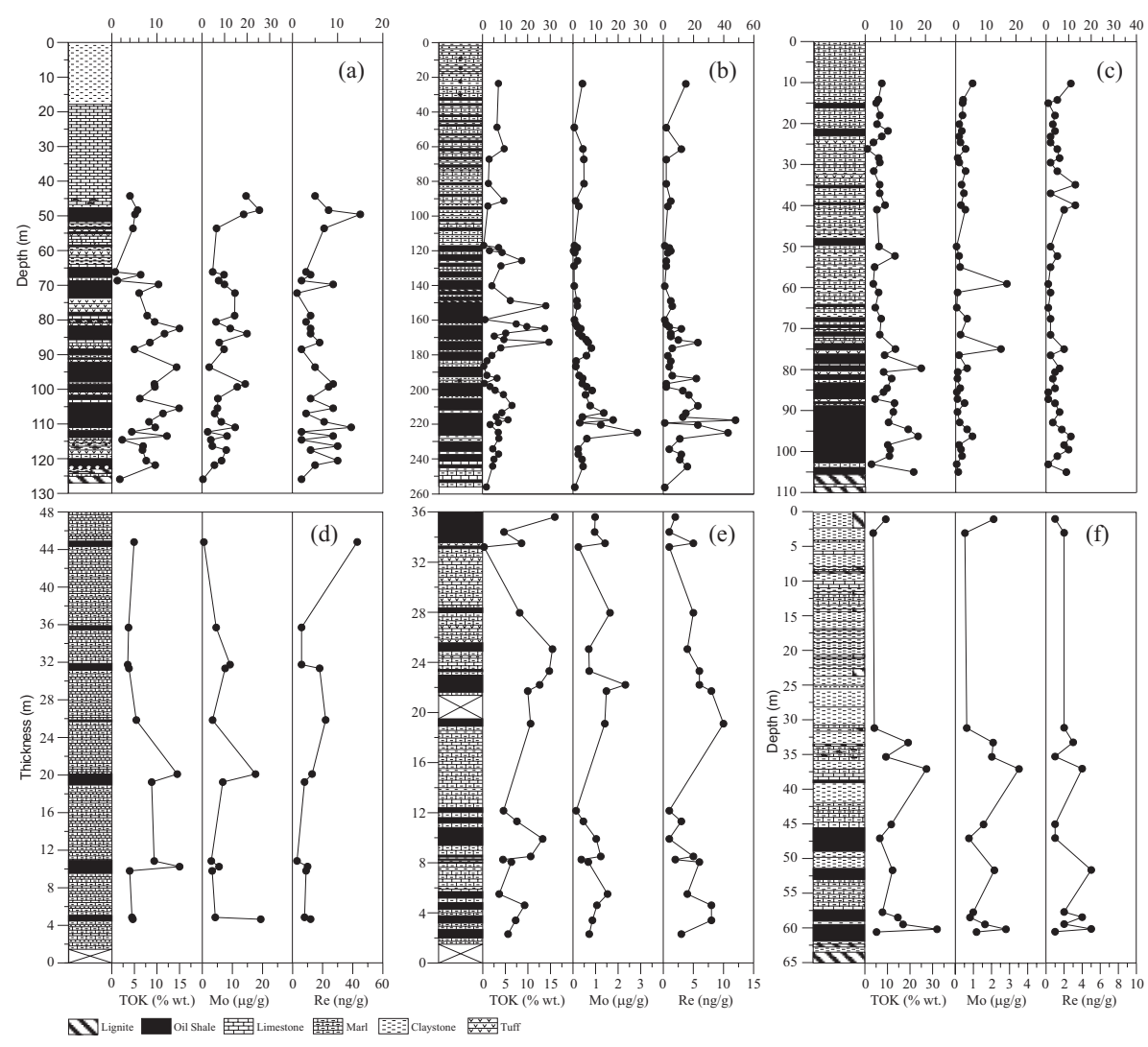

Fig. 2. Well logs and measured stratigraphic sections for oil shales, and distribution of TOC, Re and Mo content with respect to depth/thickness. (a) BB-1 (Beypazar1), (b) G-2 (Hatıldağ), (c) 88/3 (Himmetoğlu), (d) Gölpazarı, (e) Bahçecik and (f) BS-5 (Seyitömer).

Mo concentrations of oil shales from the Hatıldağ, Himmetoğlu, Beypazarı, Bahçecik, Seyitömer and Gölpazarı fields are 0.25-28.50; 0.29-17.00; $0.45-25.42 ; 0.14-2.32 ; 0.53-3.52$ and $0.51-19.41 \mu \mathrm{g} / \mathrm{g}$, respectively, and the average values are given in Table 1. Mo concentrations of the Bahçecik and Seyitömer fields vary in a narrow range, but the concentration range of the other fields is wide (Fig. 2).

$\mathrm{U}$ concentration ranges for the Hatıldağ, Himmetoğlu, Beypazarı, Bahçecik, Seyitömer and Gölpazarı fields are 0.10-5.20; 0.40-10.70; 0.20$9.50 ; 0.20-2.20 ; 0.20-1.50$ and $1.50-3.40 \mu \mathrm{g} / \mathrm{g}$, respectively. The average data are given in Table 1. Except for Himmetoğlu and Beypazan fields, U concentrations vary in a narrow range.

Re and Mo concentrations of the Hatıldağ field (Fig. 2b) and TOC values of the Himmetoğlu field (Fig. 2c) increase with depth. On the other hand, Mo concentrations of the Beypazarı field decrease with depth (Fig. 2a). 
Re concentrations of the Gölpazarı field increase with increasing thickness (Fig. 2d) and $\mathrm{U}$ concentrations decrease.

Average data for $\mathrm{Re}, \mathrm{Mo}$ and $\mathrm{U}$ content of the Norwegian black shales are $100 \mathrm{ng} / \mathrm{g}, 62 \mu \mathrm{g} / \mathrm{g}$, and $13 \mu \mathrm{g} / \mathrm{g}$, those of CTBE black shales are $210 \mathrm{ng} / \mathrm{g}, 145 \mu \mathrm{g} / \mathrm{g}$ and $18 \mu \mathrm{g} / \mathrm{g}$ [26]. Re, Mo and U contents of the Mediterranean sapropels are reported to be $330 \mathrm{ng} / \mathrm{g}, 76 \mu \mathrm{g} / \mathrm{g}$ and $17 \mu \mathrm{g} / \mathrm{g}$ [30]. Average data on TOC content of Mediterranean sapropels, Norwegian and CTBE black shale are 5.5, 7.6 and 8.9 wt.\% [26, 30]. The highest average concentrations of Re, Mo and $\mathrm{U}$ for the six fields under investigation are computed to be $10.43 \mathrm{ng} / \mathrm{g}$ (Gölpazarı), $10.17 \mu \mathrm{g} / \mathrm{g}$ (Beypazarı) and $3.30 \mu \mathrm{g} / \mathrm{g}$ (Himmetoğlu), respectively. These values are much lower than those of Norwegian and CTBE black shales and Mediterranean sapropels. This is due to the fact that Norwegian and CTBE black shales and Mediterranean sapropels are of marine origin, while oil shales studied are of lacustrine origin [12]. Considering that seawater is an important source of these elements, these lacustrine oil shales are expected to contain much less Re, Mo and U.

\section{Enrichment in Re and Mo}

Sedimentary rocks are important source for rhenium. Although Re content of the crust $(0.5 \mathrm{ng} / \mathrm{g}$ [27]) and oxic sediments $(<0.1 \mathrm{ng} / \mathrm{g} \mathrm{[31])} \mathrm{is} \mathrm{low,} \mathrm{it} \mathrm{can} \mathrm{be}$ substantially higher in TOC-rich sediments deposited under reducing conditions, and thus, $\mathrm{Re}$ is accepted as one of paleoredox elements [26-28]. In deposition environments, Re and Mo are bound to the organic matter or precipitate as individual sulfides or iron-sulfides. The available data indicate that enrichment with Re, Mo and U occurs at the sediment-water interface or below this level. Under reducing conditions, $\mathrm{Re}, \mathrm{Mo}$ and $\mathrm{U}$ are added to the sediments by their diffusion from the pore water under reducing conditions $[26,28]$.

Beypazarı, Seyitömer and Hatıldağ oil shale sequences were deposited in an anoxic environment while Himmetoğlu, Bahçecik and Gölpazarı shales were formed in a suboxic environment [12]. These oil shales are the products of a reducing deposition environment and they can be the source of Re-Mo enrichment. In these sequences, enrichment factors of elements Re, Mo and $\mathrm{U}$ with respect to average shales were computed as follows:

$$
\text { Enrichment Factor }(\mathrm{EF})=(\mathrm{element} / \mathrm{Al})_{\text {sample }} /(\mathrm{element} / \mathrm{Al})_{\text {average shale }}
$$

EF values exceeding unity indicate a relative enrichment, and values lower than unity indicate depletion [32]. Average values for Re, Mo, $\mathrm{U}$ and $\mathrm{Al}$ in shales are $0.5 \mathrm{ng} / \mathrm{g}$ [27], 2.6, $3.7(\mu \mathrm{g} / \mathrm{g}$ ) [33] and 8.8\% [34], respectively.

Aluminium is not affected by biologic or diagenetic processes and it is derived from structural components of minerals which are transported by eolian and fluvial agents. In addition, although $\mathrm{Al}$ is abundant in aluminium silicates, its concentration in the seawater is low. Therefore, it is accepted as 
the most suitable element for determining the abundance of terrigenous fractions [32]. Al concentration in oil shales and also in organic-rich sediments under investigation is much lower than that in other shales. This is attributed to the excess mass resulting from organic matter abundance in oil shales. Since terrigenous matter is the source of aluminium, a significant increase in the organic matter will cause a decrease to occur in aluminium concentration. It is shown in correlation matrix of the Hatıldağ, Himmetoğlu and Bahçecik fields that $\mathrm{Al}$ content of the oil shales decreases in parallel to the increase in organic matter (TOC) content. For the Himmetoğlu field, there is an inverse correlation $(\mathrm{r}=-0.584)$ between $\mathrm{Al}$ and TOC at a significance of $\mathrm{p} \leq 0.01$, and similarly, correlations between these parameters are inverse for the Hatıldağ and Bahçecik fields $(r=-0.350$ and -0.544 , respectively) at a significance of $\mathrm{p} \leq 0.05$.

$\mathrm{Re}, \mathrm{Mo}$ and $\mathrm{U}$ concentrations in all fields (except for the Bahçecik field) are higher with respect to average shales. Computed value of $U$ enrichment factor for the Bahçecik field indicates the depletion of uranium in this field. Considering all the fields, in general, Re and U show the largest and lowest enrichment factors, respectively. Only for the Himmetoğlu field, enrichment with $U$ is greater than with Mo. Considering these three elements, the Beypazarı field is characterized by the greatest enrichment factors $(\mathrm{EF}=$ 310.00, 107.00 and 12.45 for Re, Mo and U), and relatively high enrichment factors were also computed for the Hatıldağ and Gölpazarı fields. The enrichment with Re and Mo was lowest in the Bahçecik field ( $\mathrm{EF}=35.17$ and 1.57 for Re and Mo), and uranium with an enrichment factor less than 1 has been depleted in this field (Fig. 3; Table 2).

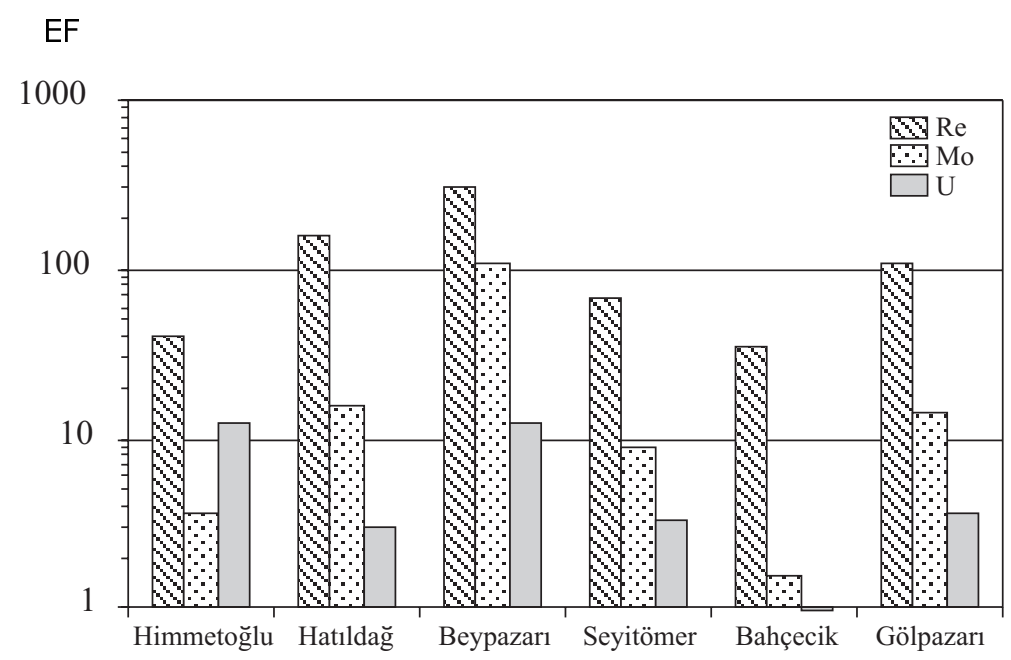

Fig. 3. Enrichment factors for the Himmetoğlu, Hatıldağ, Beypazarı, Seyitömer, Bahçecik and Gölpazarı oil shales. 
Table 2. Enrichment factors with respect to average values of shales for the Himmetoğlu, Hatıldağ, Beypazarı, Seyitömer, Bahçecik and Gölpazarı oil shales

\begin{tabular}{|l|r|r|r|}
\hline \multirow{2}{*}{ Field Name } & \multicolumn{3}{|c|}{ Enrichment Factor } \\
\cline { 2 - 4 } & $\mathrm{Re}$ & Mo & \multicolumn{1}{c|}{$\mathrm{U}$} \\
\hline Himmetoğlu & 39.50 & 3.57 & 12.45 \\
Hatıldağ & 158.17 & 15.67 & 3.07 \\
Beypazarı & 310.00 & 107.00 & 12.45 \\
Seyitömer & 67.50 & 9.07 & 3.33 \\
Bahçecik & 35.17 & 1.57 & 0.95 \\
Gölpazarı & 106.67 & 14.53 & 3.64 \\
\hline
\end{tabular}

Average values of shales for $\mathrm{Re}, \mathrm{Mo}, \mathrm{U}$ and $\mathrm{Al}$ are $0.5 \mathrm{ng} / \mathrm{g}$ [27], 2.6, $3.7(\mu \mathrm{g} / \mathrm{g})[33]$ and $8.8 \%$ [34], respectively.

\section{Correlation between Re, Mo, $\mathrm{U}$ and TOC}

Paragenetically, Re, Mo and U show a close relation to each other. Rhenium is observed in minerals of other elements, and there are a few minerals in which $\mathrm{Re}$ is the main mineral-forming element. Molybdenite is the main source of rhenium [18]. Moreover, there are also rhenium occurrences associated with uraninites $[35,36]$. Vine and Tourtelot [16] have established a relation between $\mathrm{Mo}$ and organic matter content. Organometallic components of $\mathrm{Re}$ and Mo were determined in lignites [18]. It was determined that organic matter plays an important role in absorption of uranium in organic-rich sediments or black shales being an important reducing agent for deposition of insoluble uranious forms. In addition, uranium compounds contain also some organometallic components [37].

In order to determine correlations between Re, $\mathrm{U}$ and Mo elements and TOC in the Hatıldağ, Himmetoğlu, Beypazarı, Bahçecik, Seyitömer and Gölpazarı oil shales, correlation matrices were formed, and matrices were checked if they are significant at $\mathrm{p} \leq 0.05$ and $\mathrm{p} \leq 0.01$ levels (Table 3). Significant relations were found for Re-Mo in Hatıldağ, for Re-TOC and Re-U in Himmetoğlu, for Re-Mo and U-TOC in Beypazarı, for Re-Mo and $\mathrm{Re}-\mathrm{U}$ in Bahçecik and for Re-TOC, Mo-TOC, U-TOC, Re-U and Mo-U in Seyitömer (Table 3, Fig. 4). No significant relation was found for the Gölpazarı field oil shales.

Re and Mo show positive correlations in three fields (Hatıldağ, Beypazarı and Bahçecik), Re and $\mathrm{U}$ have strong positive correlations in three fields (Himmetoğlu, Bahçecik and Seyitömer), and Mo and U are significantly positively correlated in only one field. Considering the relations between TOC content and Re-Mo-U elements, TOC shows positive correlation with rhenium in two fields (Seyitömer and Himmetoğlu), with molybdenum in one field (Seyitömer) and with uranium in two fields (Seyitömer and Beypazarı) (Table 3, Fig. 4). 
Table 3. Correlation matrix of Re, Mo, Al, $\mathbf{U}$ and TOC in the oil shales. (a) Hatıldağ, (b) Himmetoğlu, (c) Beypazarı, (d) Bahçecik, (e) Seyitömer and (f) Gölpazarı

\begin{tabular}{|c|c|c|c|c|c|c|}
\hline Depth & 1.000 & & & & \multirow{3}{*}{ (a) } & \\
\hline TOC & -.051 & 1.000 & & & & \\
\hline $\operatorname{Re}$ & $.350 *$ & .216 & 1.000 & & & \\
\hline Mo & $.348^{*}$ & .038 & $.826 * *$ & 1.000 & & \\
\hline $\mathrm{U}$ & .099 & .054 & -.119 & -.036 & 1.000 & \\
\hline \multirow[t]{2}{*}{$\mathrm{Al}$} & $-.448 * *$ & $-.350 *$ & $-.391 * *$ & $-.299 *$ & -.139 & 1.000 \\
\hline & Depth & TOC & $\mathrm{Re}$ & Mo & $\mathrm{U}$ & $\mathrm{Al}$ \\
\hline Depth & 1.000 & & & & \multirow{4}{*}{ (b) } & \\
\hline TOC & $.528 * *$ & 1.000 & & & & \\
\hline $\mathrm{Re}$ & .046 & $.450 * *$ & 1.000 & & & \\
\hline Mo & -.030 & .096 & .149 & 1.000 & & \\
\hline $\mathrm{U}$ & -.109 & .036 & $.353^{*}$ & .153 & 1.000 & \\
\hline \multirow[t]{2}{*}{$\mathrm{Al}$} & $-.880 * *$ & $-.584 * *$ & -.257 & -.150 & .070 & 1.000 \\
\hline & Depth & TOC & $\mathrm{Re}$ & Mo & $\mathrm{U}$ & $\mathrm{Al}$ \\
\hline Depth & 1.000 & & & & \multirow{4}{*}{ (c) } & \\
\hline TOC & .233 & 1.000 & & & & \\
\hline $\mathrm{Re}$ & -.024 & .299 & 1.000 & & & \\
\hline Mo & $-.509 * *$ & .130 & $.375^{*}$ & 1.000 & & \\
\hline $\mathrm{U}$ & .197 & $.478 * *$ & .114 & .239 & 1.000 & \\
\hline \multirow[t]{2}{*}{$\mathrm{Al}$} & .288 & .215 & $.441 *$ & -.019 & $.458 * *$ & 1.000 \\
\hline & Depth & TOC & $\operatorname{Re}$ & Mo & $\mathrm{U}$ & $\mathrm{Al}$ \\
\hline
\end{tabular}

\begin{tabular}{|c|c|c|c|c|c|c|}
\hline Thickness & 1.000 & & & & \multirow{4}{*}{ (d) } & \\
\hline TOC & .212 & 1.000 & & & & \\
\hline $\operatorname{Re}$ & -.198 & .288 & 1.000 & & & \\
\hline Mo & .164 & .355 & $.499 *$ & 1.000 & & \\
\hline $\mathrm{U}$ & -.296 & .215 & $.775 * *$ & .318 & 1.000 & \\
\hline $\mathrm{Al}$ & -.180 & $-.544 *$ & -.324 & -.385 & -.416 & 1.000 \\
\hline & Thickness & TOC & $\mathrm{Re}$ & Mo & $\mathrm{U}$ & $\mathrm{Al}$ \\
\hline
\end{tabular}

\begin{tabular}{|c|c|c|c|c|c|c|}
\hline Depth & 1.000 & & & & \multirow[b]{2}{*}{ (e) } & \\
\hline TOC & .310 & 1.000 & & & & \\
\hline $\mathrm{Re}$ & .315 & $.699 * *$ & 1.000 & & & \\
\hline Mo & .033 & $.807 * *$ & .478 & 1.000 & & \\
\hline $\mathrm{U}$ & .242 & $.679 * *$ & $.594 *$ & $.722 * *$ & 1.000 & \\
\hline $\mathrm{Al}$ & .242 & .200 & -.083 & .219 & $.600 *$ & 1.000 \\
\hline & Depth & TOC & $\operatorname{Re}$ & Mo & $\mathrm{U}$ & $\mathrm{Al}$ \\
\hline
\end{tabular}

\begin{tabular}{|c|c|c|c|c|c|c|}
\hline Thickness & 1.000 & & & & \multirow{4}{*}{ (f) } & \\
\hline TOC & -.305 & 1.000 & & & & \\
\hline $\operatorname{Re}$ & $.587 *$ & -.151 & 1.000 & & & \\
\hline Mo & -.294 & .245 & -.234 & 1.000 & & \\
\hline $\mathrm{U}$ & $-.681 *$ & .520 & -.087 & .132 & 1.000 & \\
\hline $\mathrm{Al}$ & .051 & .091 & -.293 & -.431 & -.039 & 1.000 \\
\hline & Thickness & TOC & $\mathrm{Re}$ & Mo & $\mathrm{U}$ & $\mathrm{Al}$ \\
\hline
\end{tabular}

$* * \mathrm{p} \leq 0.01$

$* \mathrm{p} \leq 0.05$ 

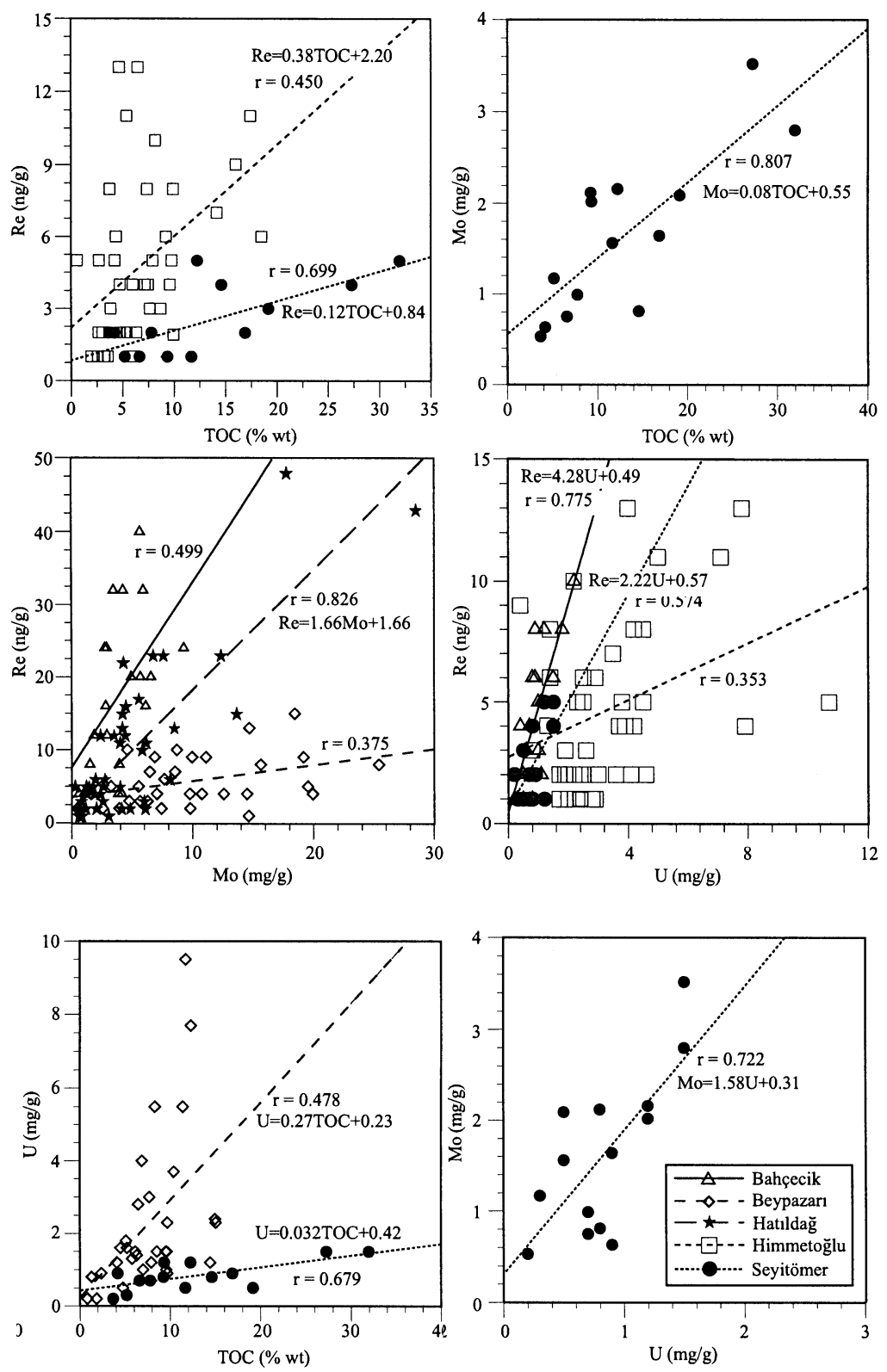

Fig. 4. Bivariate diagrams for Re, Mo, U and TOC from the Himmetoğlu, Hatıldağ, Beypazarı, Seyitömer and Bahçecik oil shale deposits (The values for the Bahçecik area in Re-Mo diagram were multipled by four).

Regression lines drawn in bivariate diagrams for Re, Mo, U and TOC data which have significant correlations were tested at $\leq 0.01$ and $\mathrm{p} \leq 0.05$ levels. Re-TOC (Seyitömer, Himmetoğlu), Mo-TOC (Seyitömer), U-TOC 
(Seyitömer and Beypazarı), Re-Mo (Hatıldağ), Re-U (Bahçecik and Seyitömer) and Mo-U (Seyitömer) distributions are represented by lines which are significant at $\mathrm{p} \leq 0.01$, and their equations are given in Fig. 4. The line representing Re-Mo correlation for the Bahçecik field (at significance of $\mathrm{p} \leq 0.01$ ) was obtained from a diagram constructed with logarithmic data, and the corresponding equation is given in Fig. 5. There is no line or relationship (at a significance of $p \leq 0.01$ and $p \leq 0.05$ ) between Re-Mo for the Beypazarı field and Re-U for the Himmetoğlu field.

In general, Re or Mo shows significant correlation with either U or TOC in different fields (except for Gölpazar1) which gives the support to postulation that there are a few minerals in which rhenium is the main mineral forming element. Rhenium is present in minerals of other elements (particularly Mo and U), and it occurs in the organometallic components.

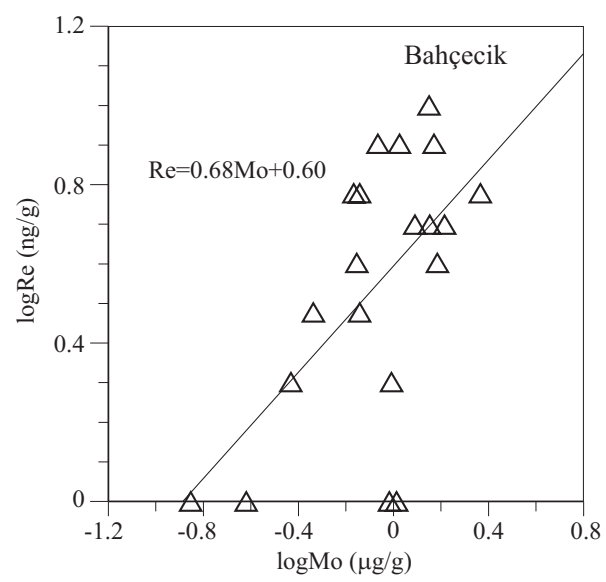

Fig. 5. Bivariate diagram and regression line for Bahçecik oil shale.

\section{Conclusions}

The average values of TOC content calculated for Hatıldağ, Himmetoğlu, Beypazarı, Bahçecik, Seyitömer and Gölpazarı oil shales indicate that these oil shales are very rich in TOC.

The average Re and Mo concentrations of the samples indicate that all fields are rich in $\mathrm{Re}$ and Mo, and enrichment with rhenium is relatively higher than that with molybdenum. The highest and lowest enrichment factors for Re were found for the Beypazarı $(\mathrm{EF}=310)$ and Bahçecik $(\mathrm{EF}=35.17)$ fields, respectively. Mo enrichment is highest in the Beypazarı field $(\mathrm{EF}=107)$ and lowest in the Bahçecik field $(\mathrm{EF}=1.57)$.

Concentrations of $\mathrm{Re}$, Mo and $\mathrm{U}$ of oil shales were correlated with the corresponding values of marine Norwegian and CTBE black shales and the Mediterranean sapropels. It was determined that average concentration of 
$\mathrm{Re}$, Mo and $\mathrm{U}$ of these rocks are much greater than those in the studied areas. Considering that seawater is an important source of these elements, very low concentrations of $\mathrm{Re}$ and Mo of the Hatıldağ, Himmetoğlu, Seyitömer, Beypazarı, Bahçecik and Gölpazarı oil shales might be attributed to the fact that these shales were deposited in a lacustrine environment.

Rhenium shows positive correlation with Mo and $\mathrm{U}$ in the Bahçecik field, with TOC and U in the Seyitömer and Himmetoğlu fields, with TOC in the Himmetoğlu field and with Mo in the Beypazarı and Hatıldağ fields. Except for Gölpazarı, rhenium is positively correlated with Mo, U and TOC in all the fields. This may indicate the scarce of minerals in which rhenium is the main element, it is mainly observed in minerals of other elements (particularly Mo and $\mathrm{U}$ ) and mostly occurs in the organometallic components.

\section{Acknowledgements}

Author thanks to Dr. Necati Tüysüz and Dr. Sadettin Korkmaz for their critical comments on the manuscript.

\section{REFERENCES}

1. Kök, M. V. Oil shale resources in Turkey // Oil Shale. 2006. Vol. 23, No. 3. P. 209-210.

2. Altun, N. E., Hiçyılmaz, C., Hwang, J.-Y., Bă̆cl, A. S., Kök, M. V. Oil shales in the world and Turkey; reserves, current situation and future prospects: a rewiev // Oil Shale. 2006. Vol. 23, No. 3. P. 211-27.

3. Talu, S., Bituminous Shale of Bahçecik (İzmit)// MTA Report No. 4667, Ankara, 1967 (unpubl.) [in Turkish].

4. Yanılmaz, E., Ipeksever, M., Aslan, N. Report on Gölpazarı (Bilecik) Bituminous Shale Field // Report No. 7060, MTA, Ankara, 1980 (unpubl.) [in Turkish].

5. Taka, M., Şener, M. Bituminous shale facility of Himmetoğlu (Göynük-Bolu) Field and Their Wells // Report No. 8533, MTA, Ankara, 1988 (unpubl.) [in Turkish].

6. Şener, M., Şengüler, I. Geology and Economic Usage of Beypazarı Bituminous Shale // Report No. 9202, MTA, Ankara, 1991 (unpubl.) [in Turkish].

7. Şener, M., Şengüler, I. Geology, Usage Facility and Firing Test Results in Fluid Bed of Seyitömer Bituminous Shale // Report No. 9441, MTA, Ankara, 1992 (unpubl.) [in Turkish].

8. Şener, M., Şengüler, I. Geology and Technologic Usage Facility of Hatıldağ (Bolu-Göynük) Bituminous Shale // Report No. 9445, MTA, Ankara, 1992 (unpubl.) [in Turkish].

9. Şener, M., Şengüler, İ., Kök, M. V. Geological consideration for the economic evaluation of oil shale deposits in Turkey // Fuel. 1994. Vol. 74, No.7. P. 999 1003. 
10. Sart, A. Organic Geochemical Investigation of Bituminous Shale of Himmetoğlu Formation (Göynük-Bolu)// 1. Western Anatolia Energy Symposium, 8-14 March, İzmir, 1999 [in Turkish with English abstract].

11. Özçelik, $O$. Organic geochemical characteristics of Miocene bituminous units, North of Beypazarı (Ankara) // Geology Bulletin of Turkey. 2002. Vol. 45. P. 1-17 [in Turkish with English abstract].

12. Kara Gülbay, R., Korkmaz, S. Organic geochemical characteristics and depositional environments of oil shales in Northwest Anatolia, Turkey // Geology Bullertin of Turkey. 2005. Vol. 48. No. 2. P. 21-41. [in Turkish with English abstract].

13. Pettijohn, F. J. Sedimentary Rocks. - Harper and Row, New York, 1957.

14. Tissot, B. P., Welte, D. H. Petroleum Formation and Occurence. - Springer Verlag, Berlin Heidelberg, New York, Tokyo, 1984.

15. Goldschmidt, V. M. Geochemistry. - Oxford University Press, 1954.

16. Vine, J. D., Tourtelot, E. B., Geochemistry of black shale deposits - a summary report // Economic Geology. 1970. Vol. 65, No. 3. P. 253-272.

17. Wignall, P. B. Black Shales. - Clarendon Press, Oxford, 1994.

18. Morris, D. F. C., Short E. L. Rhenium // Handbook of Geochemistry, Vol. II/1 / K. H. Wedepohl, C. W. Correns, D. W. Shaw, K. K. Turekian, J. Zemann (Eds.). Springer-Verlag Berlin, Heidelberg, New York. 1969.

19. Halberg, R. O. A geochemical method for investigation of paleoredox conditions in sediments // Ambio Special Report. 1976. Vol. 4. P. 139-147.

20. Dypvik, $H$. Geochemical composition and depositional conditions of Upper Jurassic and Lower Cretaceous Yorkshire clays, England// Geochemical Magazine. 1984. Vol. 121, No. 5. P. 489-504.

21. Brumsack, H.-J. Geochemistry of Cretaceous black shales from Atlantic ocean (DSDP Legs 11, 14, 36 and 41) // Chem. Geol. 1980. Vol. 31. P. 1-25.

22. Brumsack, H.-J. The organic geochemistry of Cretaceous black shales (DSDP leg 41) in comparison to modern upwelling sediments from the Gulf of California // North Atlantic Paleoceanography / N. J. Shackleton, C. P. Summerhayes (Eds.). Geol. Soc. Spec. Publ. 1986. Vol. 21. P. 447-462.

23. Dill, $H$. Metallogenesis of Early Palaeozoic graptolite shales from the Graefenthal Horst (North Bavaria-Federal Republic of Germany) // Economic Geology. 1986. Vol. 81. P. 889-903.

24. Hatch, J. R., Leventhal, J. S. Relationship between inferred redox potential of the depositional environment and geochemistry of the Upper Pennsylvanian (Missourian) Stark Shale Member of the Dennis Limestone, Wabaunsee Country, Kansas, USA // Geochemistry of metalliferous black shale / P. A. Meyers, L. M. Pratt, B. Nagy (Guest eds.). Chemical Geology. 1992. Vol. 99, P. 65-82.

25. Piper, D. Z. Seawater as the source of minor elements in black shales, phosphorites and other sedimentary rocks // Chemical Geology. 1994. Vol. 114, No. 1-2. P. 95-114.

26. Lipinski, M., Warning, B., Brumsack, H.-J. Trace metal signatures of Jurassic/ Cretaceous black shale from Norwegian Shelf and the Barents Sea // PALAEO. 2003. Vol. 190. P. 459-475.

27. Crusius, J., Calvert, S., Pedersen, T., Sage, D. Rhenium and molybdenum enrichments in sediments as indicators of oxic, suboxic and sulfidic conditions of deposition // EPSL. 1996. Vol. 145, No. 1-4. P. 65-78. 
28. Colodner, D., Edmond, J., Boyle, E. Rhenium in the Black Sea: comparison with molybdenum and uranium // EPSL. 1995. Vol. 131, No. 1. P. 1-15.

29. Sarı, A. Economic Geology of Lignite from Himmetoğlu Village (GöynükBolu) // Msc Thesis, Ankara University, Ankara, 1985 [in Turkish with English abstract].

30. Warning, B., Brumsack, H.-J. Trace metal signatures of Eastern Mediterranean sapropels // PALAEO. 2000. Vol. 158, No. 3-4. P. 293-309.

31. Koide, M., Hodge, V. F., Yang, J. S., Stallard, M., Goldberg, E. G., Calhoun, J., Bertine, $K$. K. Some comparative marine chemistries of rhenium, gold, silver and molybdenum // Applied Geochemistry. 1986. Vol. 1, No. 6. P. 705-714.

32. Brumsack, H.-J. The trace metal content of recent organic-rich sediments: implications for Cretaceous black shale formation // PALAEO. 2006. Vol. 232, No. 2-4. P. 344-361.

33. Wedepohl, K. H. Environmental influences on the chemical composition of shales and clays // Physics and chemistry of the earth / L. H. Ahrens, F. Pres, S. K. Runcorn, H. C. Urey (Eds.). Pergamon, 1971. P. 307-331.

34. Bowen, H. J. M. Environmental chemistry of the elements. - Academic Press, London, 1979.

35. Petersen, R. G., Hamilton, J. C., Myers, A. T. An occurence of rhenium associated with uraninite in Coconino Country, Arizona // Economic Geology. 1959. Vol. 54, No. 2. P. 254-267.

36. Myers, A. T., Wilmarth, V. R. A study of rhenium and molybdenum in uranium ore from the Runge Mine, Fall River Country, South Dakota, by means of a spectrographic and concentration method // U. S. Geol. Survey. Profess. Papers. 1960. No. 400-B, P. 39-41.

37. Rogers, J. J. W., Adams, J. A. S. Uranium // Handbook of Geochemistry. Vol. II/1 / K. H. Wedepohl, C. W. Correns, D. W. Shaw, K. K. Turekian, J. Zemann (Eds.). Springer-Verlag Berlin, Heidelberg, New York, 1969.

Presented by M. V. Kök

Received March 1, 2007 